\title{
Pulmonary Alveolar Microlithiasis with Homozygous c.316G>C (p.G106R) Mutation: A Case Report
}

\section{Homozigot c.316G>C (p.G106R) Mutasyonu olan Pulmoner Alveoler Mikrolitiazis Olgusu}

\author{
İrem Hicran ÖZBUDAK', Cumhur İbrahim BAŞSORGUN', Gülay ÖZBíLiM', Güven LÜLECi², Alpay SARPER, \\ Abdullah ERDOĞAN ${ }^{3}$, Fulya TAYLAN ${ }^{4}$, Ender ALTIOK ${ }^{4}$ \\ Departments of ${ }^{1}$ Pathology, ${ }^{2}$ Medical Biology and ${ }^{3}$ Chest Surgery, Akdeniz University, Faculty of Medicine, ANTALYA, TURKEY, \\ ${ }^{4}$ Acıbadem Genetic Diagnosis Center, ISTANBUL, TURKEY
}

\begin{abstract}
Pulmonary alveolar microlithiasis is characterized by the presence of calcospherites in alveolar spaces. Sporadic cases are more common, but the disease also presents in an inherited familial form. The greatest number of reported cases is from Europe and especially Turkey. We present a 43-year-old female with complaints of dyspnea for many years. She had a suspicious familial history of pulmonary alveolar microlithiasis. The surgical lung biopsy specimen appeared gritty and firm. Histological sections showed diffuse involvement of the lung parenchyma by innumerable tiny calcospherites. Genetic studies showed a homozygous c.316G>C (p.G106R) mutation in exon 4 and confirmed the diagnosis of pulmonary alveolar microlithiasis. The present report aims to contribute to the literature with a pathologically and genetically confirmed new case to add insight into the etiology of this rare disease. This case confirms an autosomal recessive inheritance and does not support the role of non-genetic and other factors in the pathogenesis of pulmonary alveolar microlithiasis.
\end{abstract}

Key Words: Homozygous c.316G>C (p.G106R) mutation, Pulmonary alveolar microlithiasis, SLC34A2 protein

\section{INTRODUCTION}

Pulmonary alveolar microlithiasis (PAM) is a rare disease, first described by Harbitz in 1918 (1). It is characterized by deposition of calcium and/or phosphate microliths in the alveolar spaces secondary to disturbances in calcium and/or phosphate homeostasis. It affects all age groups and shows a predilection for male sex in the sporadic form that is more common. The disease also presents in an inherited familial form and females are more affected in familial cases. A familial predisposition has been pointed out by

(Turk Patoloji Derg 2012, 28:282-285)

Received : 09.02.2011 Accepted : 17.02.2011
ÖZ

Pulmoner alveoler mikrolitiazis, alveoler boşluklar içinde kalkosferitlerin varlı̆̆ı ile karakterizedir. Sporadik olgular daha sık görülür, ancak hastalık, kalıtsal ailesel formda da karşımıza çıkmaktadır. Literatürdeki olguların büyük kısmı Avrupa'dan ve özellikle Türkiye'den rapor edilmiştir. Olgumuz 43 yaşında kadın hasta olup uzun yıllardır olan dispne şikayeti ile başvurmuştur. Özgeçmişinde kuşkulu pulmoner alveoler mikrolitiazis aile öyküsü dikkati çekmektedir. Cerrahi biyopsi ile örneklenen akciğer dokusu makroskopik olarak kumsu ve sert özelliktedir. Mikroskopisinde akciğer parankiminin difüz olarak çok sayıda küçük kalkosferitler ile tutulduğu izlenmiştir. Genetik olarak olgumuzda ekson 4'de homozigot c.316G >C (p.G106R) mutasyonu gösterilmiş ve bu sonuç ile pulmoner alveoler mikrolitiazis tanısı genetik olarak da doğrulanmıştır. Bu makalede literatüre ek olarak, patolojik ve genetik pulmoner alveoler mikrolitiazis olduğu kanıtlamış yeni bir olgu sunulmuş ve bu nadir hastalığın etiyolojisi tartışılmıştır. Olgumuz pulmoner alveoler mikrolitiazisin otozomal resesif kalıtımla geçişini göstermekte ve pulmoner alveoler mikrolitiazisin patogenezinde adı geçen diğer genetik olmayan faktörlerin varlığını desteklememektedir.

Anahtar Sözcükler: Homozigot c.316G>C (p.G106R) mutasyonu, Pulmoner alveoler mikrolitiazis, SLC34A2 proteini several authors, with the frequency varying between $38 \%$ and $61 \%$, indicating the relevant role of the genetic factors (2). The highest number of cases has been reported from Europe, followed by Asia, especially Asia Minor, while the single nations with the greatest number of reported cases are Turkey, followed by Italy and the USA (3). In addition, some of the patients reported from other countries were ethnically Turks (4). The reason for this disease distribution is not clear. The high proportion of familial cases among Turkish and Italian case series could indicate a founder
Correspondence: İ́rem Hicran ÖZBUDAK

Department of Pathology, Akdeniz University, Faculty of Medicine, ANTALYA, TURKEY

E-mail: iremhicrang@hotmail.com Phone: +90 5052589848 
gene effect (2). Here, we report a symptomatic patient with genetically and pathologically proved diagnosis of PAM who had also typical clinical and radiological changes with a suspicious family history.

\section{CASE REPORT}

A 43-year-old woman presented with non-productive cough and dyspnea on exertion intermittently for 6 months. She had no significant past history of chest disease but a suspicious familial history of PAM was noted. One of her siblings had died at 35 years of age due to chronic respiratory failure with a chest X-ray which could be compatible with PAM. There was no known previous history of disturbances in metabolism, dust exposure, or any other relevant condition. On physical examination, her vital signs were normal except for chest auscultation that revealed decreased breath sounds.

A chest X-ray showed diffuse fine bilateral micronodular opacities without evidence of air space consolidations or marked fibrosis. High resolution computed tomography (HRCT) of the chest revealed the characteristic calcified micronodulations in the lung parenchyma. The micronodules were sharply defined and measured less than $1 \mathrm{~mm}$ in diameter. The disease diffusely involved all lung fields.

Pulmonary function tests showed a forced vital capacity (FVC) of 1.73 liters (67\% predicted); a forced expiratory volume in $1 \mathrm{~s}$ (FEV1) of 1.67 liters (76\% predicted) and an FEV $1 /$ FVC ratio of $120 \%$. Results of room air arterial blood gas analysis were as follows: $\mathrm{PaCO}_{2} 33.5 \mathrm{mmHg}, \mathrm{PO}_{2} 61$ $\mathrm{mmHg}$, O2 saturation $93.2 \%$ and $\mathrm{pH} 7.48$.

The patient subsequently underwent surgical lung biopsy. Grossly, the specimen appeared gritty and firm, requiring a chemical decalcification procedure. Histological sections showed diffuse involvement of the lung parenchyma by calcific concretions filling the alveoli. These concretions had a lamellar appearance with concentric "onionskin" morphology (Figure 1A). The alveolar walls were mostly normal but focally mild interstitial fibrosis was appreciated. Bronchiolar epithelia showed no abnormality. On histochemical studies, calcospherites were highlighted by von-Kossa and periodic acid-Schiff (PAS) stains (Figure 1B).

Genetic testing for SLC34A2 gene was done PCR and DNA sequencing of the coding regions as described previously (5). A homozygous c.316G>C (p.G106R) mutation found in exon 4 confirmed the PAM diagnosis (Figure 2).
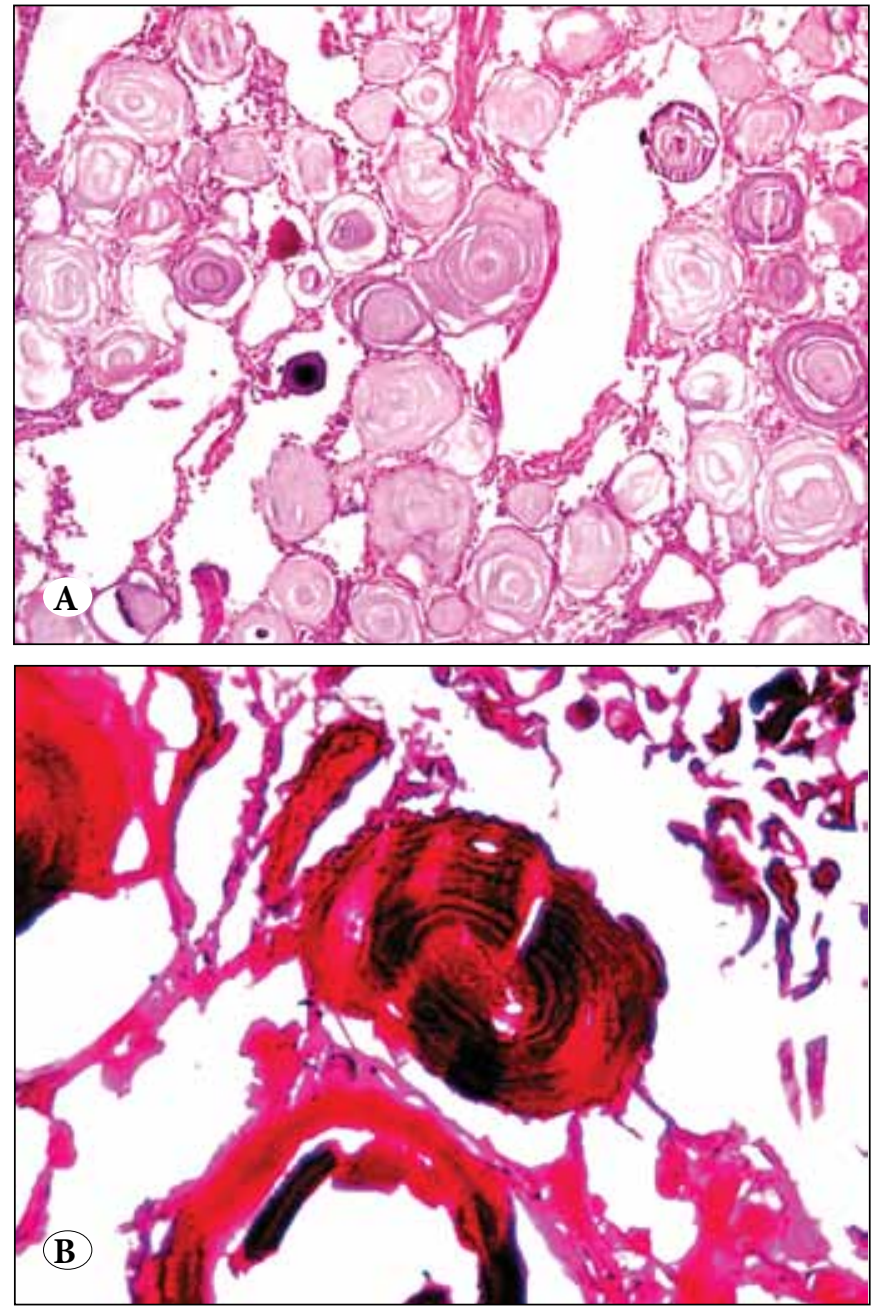

Figure 1: (A) Diffuse involvement of the lung parenchyma by calcific concretions filling the alveoli ( $\mathrm{H} \& \mathrm{E} \mathrm{x} 5)$, (B) Calcospherites are highlighted by von-Kossa stain (x40).

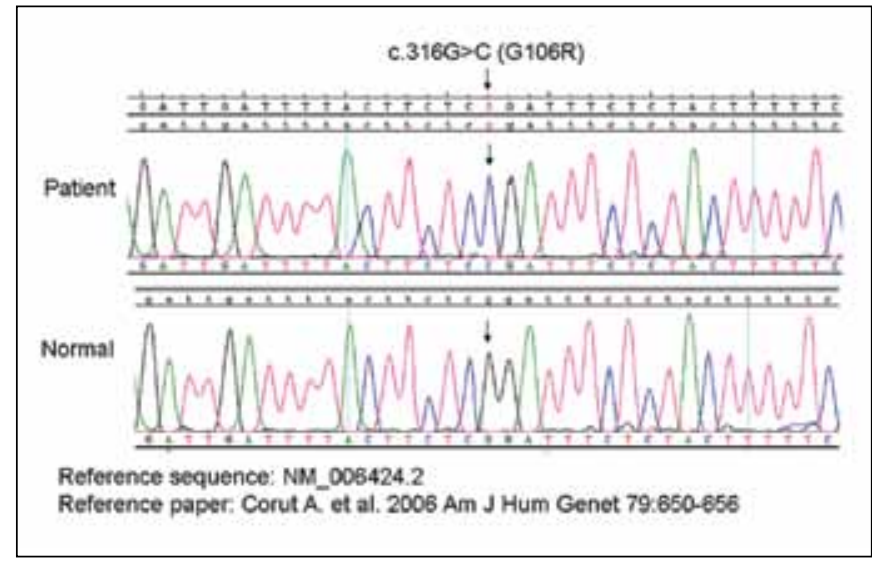

Figure 2: Genetic testing for SLC34A2 gene shows homozygous c.316G $>C$ (p.G106R) mutation in exon 4 which confirms the PAM diagnosis. 


\section{DISCUSSION}

Pulmonary alveolar microlithiasis is a rare disease of unknown etiology, characterized by progressive intraalveolar formation and accumulation of round shaped, tiny, calcific concretions (calcospherites or microliths) inside the alveoli. The total number of reported cases so far is over 550 (6). It has been reported predominantly in Mediterranean countries for unknown reasons $(3,7,8)$. The analysis of reported cases reveals that the disease is prevalent amongst family units. This provides support for the hypothesis that the disease may be hereditary and related to an underlying autosomal recessive gene disorder. Furthermore, more recent reports support this hypothesis by localizing the gene responsible for PAM in a large family and identifying homozygous mutations in SLC34A2 (the type IIb sodiumphosphate cotransporter gene) in the patients studied (5).

The genetic studies in the current case showed that there is homozygous c.316G $>\mathrm{C}$ (p.G106R) mutation in exon 4 and confirmed the diagnosis because this mutation has previously been shown to be associated with PAM in a Turkish family (5).

Sporadic cases are more common and several hypotheses have been recommended such as inhalation of specific powders and a possible condensation of alveolar mucus which were thought to be involved in the origin of microliths (9). A previous study indicated that the lung mucociliary function was impaired in patients with microlithiasis, which may represent a pathogenetic factor capable of favoring the formation of alveolar microliths (10). Furthermore, the possibility either of an alveolar thesaurotic process or an alveolar congenital enzymatic defect have also been also proposed (9).

The incidence is higher in age brackets between 20 to 50 years. However, a case of neonatal microlithiasis and a case occurring at the age of 80 years were also reported $(9,11)$. The disease has preference for the female sex in familial cases and shows a predilection for the male sex in the sporadic form (3). The age and the gender of the present case are also compatible with the literature.

Most of the patients follow a protracted course. As the disease progresses, the patients may complain of dyspnea, nonproductive cough, hemoptysis and symptoms of cor pulmonale. Deaths have occurred from 5 to 41 years after the initial diagnosis $(9,12)$. The lungs worsen over time at different rates, leading to pulmonary fibrosis, respiratory failure and chronic pulmonary heart disease. Although pulmonary function tests may initially show normal results, more severely affected patients demonstrate a restrictive pattern along with impaired diffusion capacity (3). The current case presented with exertional dyspnea and nonproductive cough. She did not show pulmonary functional abnormalities despite the decreased breath sounds on physical examination, perhaps because she was discovered at an early stage.

The diagnosis of PAM can be based on transbronchial or surgical lung biopsy, bronchoalveolar lavage (BAL), or radiographic findings of high-density interstitial lung parenchyma changes, notably on chest HRCT. A "sandstorm" picture with diffuse high-density micronodules that scatter symmetrically throughout both lung fields with middle and lower lobe predominance characterizes the chest X-ray. HRCT shows unique and characteristic calcified reticular pattern and thickening of the interlobular septa of the lung parenchyma giving the overall appearance of a "stony lung", with predominant basal and peripheral lung distribution (3). The patient's chest X-ray and HRCT findings were also found to be compatible with PAM.

The centers of microliths seen in PAM are nuclei exhibiting the polysaccharide mucoprotein complexes of cellular origin. It has been supposed that they are initially produced in the interstitial region, and that these nucleoli subsequently migrate to the alveolar spaces (13). There is gradual lamellar deposition of calcium phosphate mixed with small amounts of magnesium and aluminum around the center. The diameter of microliths is about $0.2 \mu$ and they may fill the pulmonary alveolus, whose wall and septum may appear to be pressed. On histochemical studies, microliths are PAS positive and the von Kossa stain can show the calcium ingredient. In the present case, histology of the lung biopsy revealed typical laminated microliths which were PAS- and von Kossa-positive in keeping with the diagnosis of PAM.

From the clinical and radiological perspective, the differential diagnosis of PAM includes miliary pulmonary tuberculosis, pneumoconiosis, pulmonary hemosiderosis, anthracosis and silicosis. At this point, lung biopsy, although invasive, is confirmatory.

Therapeutic methods include BAL, based on the drainage of the liquid to remove the majority of microliths from alveolus, systemic corticosteroids and oral administration of disodium etidronate. Most patients only benefit from lung transplantation (3), and our case is also pending lung transplantation.

The present report aims to contribute to the literature with a new pathologically and genetically proven case to add insight into the etiology of this rare disease. The Turkish race should particularly be investigated for the genetic 
inheritance in terms of possessing the greatest number of reported cases in worldwide. This case confirms autosomal recessive inheritance and does not support the role of other, non-genetic, factors in the pathogenesis of pulmonary alveolar microlithiasis. No valid therapy is presently able to check the relentless course toward progressive respiratory failure. The disorder may show rapid progression in some cases, probably due to the severity of the genetic disturbance. Effective treatment modalities might be developed after the etiology of PAM has been fully understood.

\section{REFERENCES}

1. Harbitz F: Extensive calcification of the lungs as a distinct disease. Arch Intern Med 1918, 21:139-146

2. Castellana G, Gentile M, Castellana R, Fiorente P, Lamorgese $V$ : Pulmonary alveolar microlithiasis: clinical features, evolution of the phenotype, and review of the literature. Am J Med Genet 2002, 111:220-224

3. Castellana G, Lamorgese V: Pulmonary alveolar microlithiasis. World cases and review of the literature. Respiration 2003, 70:549-555

4. Schmidt H, Lorcher U, Kitz R, Zielen S, Ahrens P, Konig R: Pulmonary alveolar microlithiasis in children. Pediatr Radiol 1996, 26:33-36

5. Corut A, Senyigit A, Ugur SA, Altin S, Ozcelik U, Calisir H, Yildirim Z, Gocmen A, Tolun A: Mutations in SLC34A2 cause pulmonary alveolar microlithiasis and are possibly associated with testicular microlithiasis. Am J Hum Genet 2006, 79:650-656
6. Deniz O: Pulmonary alveolar microlithiasis. Tuberk Toraks 2005, 53:293-298

7. Senyigit A, Yaramis A, Gurkan F, Kirbas G, Buyukbayram H, Nazaroglu H, Alp MN, Topcu F: Pulmonary alveolar microlithiasis: a rare familial inheritance with report of six cases in a family. Contribution of six new cases to the number of case reports in Turkey. Respiration 2001, 68:204-209

8. Ucan ES, Keyf AI, Aydilek R, Yalcin Z, Sebit S, Kudu M, Ok U: Pulmonary alveolar microlithiasis: review of Turkish reports. Thorax 1993, 48:171-173

9. Lauta VM: Pulmonary alveolar microlithiasis: an overview of clinical and pathological features together with possible therapies. Respir Med 2003, 97:1081-1085

10. D’Addabbo A, Fratello A, Fanfani G, Mele M, Dammacco F: Lung scanning and clearance of inhaled radiogold (198Au) particles in three patients with microlithiasis. Rofo 1981, 135:296-300

11. Sears MR, Chang AR, Taylor AJ: Pulmonary alveolar microlithiasis. Thorax 1971, 26:704-711

12. Moran CA, Hochholzer L, Hasleton PS, Johnson FB, Koss MN: Pulmonary alveolar microlithiasis. A clinicopathologic and chemical analysis of seven cases. Arch Pathol Lab Med 1997, 121:607-611

13. Kawakami M, Sato S, Takishima T: Electron microscopic studies on pulmonary alveolar microlithiasis. Tohoku J Exp Med 1978, 126:343-361 